\section{Logico- Semantic Relations in Bataknese Traditional Wedding Ceremony}

\section{Feriyanti Elina Gultom}

Universitas Negeri Medan, Indonesia

Email: fyantigultom2@gmail.com

\section{Abstract:}

This article explores the logico-semantic relation in communication in Bataknese traditional wedding ceremony. The dominant relation to communicate meanings as such offspring, prosperity, dignity, health, and long life of the wed are in the context of register, culture, text purpose, and ideology of Bataknese in delivering a wedding speech. Logico-semantic relation system and contextual components function as a network system to communicate sociocultural meanings in a wedding speech. This study was also aimed to identify the types of logical relations and the use of logical relations in Bataknese traditional wedding ceremony. This study was conducted by applying descriptive qualitative method. The source of data was taken from the utterancess of Parhata in Bataknese traditional wedding ceremony. The technique for analyzing the data was descriptive qualitative research based on Hancock. The result of this research was types of logical relations found in Bataknese traditional wedding ceremony, namely paratactic enhancement $(33.75 \%)$, hypotactic enhancement $(28.75 \%)$, paratactic extension (15\%), paratactic elaboration (12.5\%), hypotactic elaboration (6.25\%), hypotactic extention (2.5\%), and paratactic locution (1.25\%). And the realized of logico-semantic relations in Raja Parhata's utterances mostly appears by using conjunction jadi (so), molo (if) and holani (that all), adverbial clause dungi (after that), verb baen (play) and preposition tu (to).

Keywords:

logico-semantic relation; bataknese; traditional wedding ceremony

\section{Introduction}

People produce clauses as the representation of their ideas. Those clauses are combined to produce meanings which can be understood by others. The clauses which are logically connected is termed as clause complex. Halliday (1994: 373) states two basic systems which rule the relation of the clauses; taxis and logico-semantic relation.

Logico-semantic relation refers to the meaning that exists between paratactic and hypotactic relations, it is about relationship between or among clauses in representing ideas. The logico-semantic relations also have the realization with conjunction and adverb, so on. This relation is both logical and semantic. Halliday (2014:611) defines logico-semantic that are manifested in the system of conjunction into the two elements, expansion and projection of clause complexing. The logico-semantic relation, which very varied, since they represent the way the speaker sees the connection to be made between on clause or another. Logicosemantic relation is the relation which indicates the meaning formed when a clause is combined with another in a clause complex

Siahaan \& Napitupulu (2014) analyzed the logico meaning in wedding speech of batak toba languange. This research showed that both logico semantic relation (expansion \& projection) exist in Batak Toba language and also has the similiarity with other language is 


\section{Linglit Journal: Scientific Journal of Linguistics and Literature \\ ISSN: 2774-4523 (Online), 2774-4515 (Print) \\ Vol. 1, No. 1, December 2020, Page: 12-18 \\ Email: linglitjournal@gmail.com}

expressing the experiences through ideational function of language. Another research Sulistyaningrum \& Rasyid (2015) studied about The Logico Semantic Relations of Students ${ }^{\text {ee }}$ Presentation in Acceleration Program of SMA Labschool Jakarta. The finding in the study showed that the clause complexity in the acceleration students' presentation is varied. The girls have produce 169 clause nexus, while boy students produce 68 clause nexus. The dominant type of logico-semantic relation in girl $^{\text {lee }} \mathrm{s}$ presentation is elaboration.

A wedding speech in the tradition of Bataknese community is a natural text dominated by logico-semantic relation system. At the moment, only few old members of the community have the command in delivering the speech in a traditional wedding ceremony. No document providing information why the majority of the population avoid their compulsory task to deliver it. The root of the problem can be related to systemic functional linguistic traits of the speech as a spoken text. It is theoretically assumed that the trait complexity of the text evolves from the network system between linguistic systems which is dominated by logico-semantic relation.

This study is considered significant to enrich the study in the field of functional grammar, particularly in a clause complex analysis, in which this research focusing on the theory of taxis, logico-semantic relation, and logical meanings as well.

\section{Review of Literatures}

Halliday (2014:611) defines logico-semantic that are manifested in the system of conjunction into the two elements, expansion and projection of clause complexing. The logicosemantic relation, which very varied, since they represent the way the speaker sees the connection to be made between on clause or another. Logico-semantic relation is the relation which indicates the meaning formed when a clause is combined with another in a clause complex.

Saragih (2014:111) states that logical function in text is described with reference to two aspects, namely status and logico-semantic relations. Status refers to interdependency (which clause is dependent on which clause) between or among clauses, which is technically termed as taxis. There are two kinds of taxis, namely parataxis that refers to equal status and hypotaxis refers to an unequal status. While logico semantic-relations refers to the meaning that exists between paratactic and hypotactic relations. There are two kinds of meaning in relations namely expansion and projection.

\subsection{Logico-Semantic Relation}

Logico-semantic relation is the relation which indicates the meaning formed when a clause is combined with another in a clause complex. It is about relationship between or among clauses in representing idea.

\section{a. Paratactic Elaboration}

Paratactic elaboration $(1=2)$, the relationship may be made explicit by conjunctive expressions such as or (rather), in other words, that is to say or mean; or, in writing.

\section{b. Hypotactic Elaboration}

Hypotactic elaboration $(\alpha=\beta)$, Halliday (2004:399) states that it is the combination of elaboration with hypotactic gives the category of non-definingbrelative clause (also called 'nonrestrictive', 'descriptive'). 


\section{c. Paratactic Extension}

Paratactic extension is marked with $1+2$. In a paratactic extension the clauses in a nexus are linked together by conjunctions and, or, but.

\section{d. Hypotactic Extension}

Hypotactic extension is symbolized as $\alpha+\beta$. Hypotactic extension of this type can be recognized through the use of conjunctions while or whereas, except, that, but, etc.

\section{e. Paratactic Enhancement}

The circumstantial feature is typically expressed: (a) by the conjunctions then, so, for, but, yet, still; (b) by a conjunction group with and: and then, and there, and thus, and so, and yet; or (c) by and in combination with a conjunctive such as at that time, soon afterwards, till then, in that case, in that way. Some conjunctives, such as meanwhile, otherwise, therefore, however, nevertheless, are extending their use in modern spoken English Halliday (2004:413).

\section{f. Hypotactic Enhancement}

Hypotactically enhancing clauses may be finite or non-finite. The finite ones are introduced by a binder ('subordinating conjunction'). The non-finite are introduced either by a preposition such as on, with, by functioning conjunctively-note that sometimes the same word is both conjunction and conjunctive preposition, for example before, after; or by one of a subset of the binders- there are a few of these, such as when, which can function also with a non-finite clause Halliday (2004:416).

\section{g. Paratactic Locution}

In paratactic locution, the linguistic experience is projected as quoting. Double quotation marks (") is used to signal the projected clause in paratactic locution.

\section{h. Hypotactic Locution}

The linguistic experience in hypotactic locution is projecting as meaning or mostly known as reporting. Bloor and Bloor (2004:195) state that hypotactic locution discusses reported/indirect speech in terms of functions sayer and reported.

\section{i. Paratactic Idea}

According to Halliday (2004:456) paratactic idea indicates the same linguistic experience as paratactic locution that is quoting but in this case mental processes are used.

\section{j. Hypotactic Idea}

While hypotactic idea indicates linguistic experience which is projected as reporting by using mental processes. Like the hypotactic locution clauses in hypotactic idea whether projected or projecting clauses are also irreversible. The relationship of hypotactic idea is symbolized as $\alpha^{\prime} \beta$.

\subsection{Logical Semantic Relation Realization} a. Conjunction

There are three types of conjunctions are subordinating conjunctions (after, because, if that, though, although, till, before, unless, when, where, while), coordinating conjunctions (and, but, for, or nor, also) and correlative conjunctions (either-or, neither-nor, both-and, tought-yet, whether, not only-but also). 


\section{b. Preposition}

A preposition used to connect a noun or pronoun to a verb or adjective in a sentence, a preposition word like in, to, for, out of. Preposition divided into preposition of place (in/into, on/onto, down, under, near, away from, beside, behind, in from of, round, against, between, beyond), prepositions of time (at, on, in, during, over, for, since, till/until, by, from, between).

\section{c. Prepositional Phrase}

A prepositional phrase is a group of words including a preposition and a noun or its equivalent.

\section{d. Verb}

Verb is a part of speech which is used to demonstrate an action or a state of being. The verbs have the following forms namely, regular verb (arrive, arrived, arrived) an irregular verb (break, broke, broken).

\section{e. Adverbial Clause}

Adverbial clauses divided in to three types namely, clause of time (while, after that, whenever/every time, just as, as soon/Immediately), clause of reason (seeing (that), now (that), because of, due to, in view of, on account of).

\subsection{Bataknese Wedding Ceremony}

Batak is a tribe that originally lives in Northern part of Sumatra Island, Indonesia. There exist six kinds of Batak in Indonesia: Toba, Simalungun, Mandailing, Karo, Pakpak, and Nias. But usually, if someone only mention that he is batak people, it can be conclude that he is from Batak toba tribe. Batak tribe live in different areas, thus, own moderately different traditions. Principally, Batak traditions are operated to organize the relationships of Batak people. So, the traditions are sort of regulations within Batak.

Dalihan $\mathrm{Na}$ Tolu is the principle tradition of Batak. It is a triangle bond between brothers, sisters, and brothers of the mother. In a Batak wedding ceremony dalihan na tolu of the groom and dalihan na tolu of the bride will be involved. Terre is a Batak Toba. The Batak wedding traditions, as follow, are based on Batak Toba traditions.

Before the wedding, there is such thing call pre-wedding. This phase starts with searching for a Batak woman. Batak grooms have to search among the other 451 marga, clan, for a wife since the tradition stipulates that a man may not marry a woman from his own clan. In Batak traditions, it is taboo for a woman coming initially to a man. Both being in love and decided to get married, the next step is marhusip, which is having the groom's representative visiting the bride's family. However, since a Batak can only marry another Batak, Steve has to be adopted by a willing Batak clan and thereby marry a Batak wife according to tradition. Steve will be adopted by Gultom family and receive Gultom as his Batak marga.

At marhusip, the groom and his Batak family (core family) will visit the bride's family to discuss ensue between the two families to determine if everyone is in agreement with the marriage, what the dowry will be, where the wedding will be held, how many people will be invited, what the wedding will cost, and who will pay for it. Men and women are separated during these discussions, with the men making all the decisions. Once an agreement has been achieved, the next ceremony is called marhata sinamot. Somehow this ceremony is similar to the marhusip discussion but dalihan na tolu of the groom and the bride are involved. 
The main step of pre wedding is martumpol, the engagement. This ceremony takes place in a church. The groom and the bride vow their desires to get marry and promise to build a Christian family in front of the church elders and dalihan na tolu of both. After martumpol each family get together at their own place to prepare their parts for the wedding ceremony. The ceremony is called martonggo raja by the groom's side and marria raja by the bride's side. In a Batak wedding, families are the wedding organizers. The families will discuss about details, such as who will be raja parhata (master of ceremony), the representative at giving the gifts, the representative at receiving the gifts, the timetable, etc.The wedding day is started with marsibuhai-buhai, having breakfast together at the bride's. The groom will take the bride to the church for a holy matrimony. Afterwards the bride, the groom, and the families will have a Batak wedding ceremony. Typical affirmation of Batak wedding is as follow:

The wedding is attended by dalihan na tolu and neighbours of the groom and the bride. The groom's family gives the bride's family Namargoar ni juhut, A head, some ribs, a tail part of a cow, a buffalo, or a pig that are arranged and cooked in Batak style. The bride's family then gives the groom's family dengke, some goldfish that are cooked in Batak style. These gifts are exchanged before lunch.

Somba ni adat and somba ni uhum, offerings usually money, will be given by the groom's family to the bride's.

At least five ulos, traditional Batak cloth like a sarong, ulos na marhadohoan (meaning ulos that is produced for a special occasion) will be given by the bride's family to the groom's. The newlyweds will receive at least two ulos holong (meaning ulos that is given based on love) from the parents and the families.

\subsection{Parhata/Raja Parhata}

Raja Parhata is chosen by an agreement to lead and control of the execution of the events He has a very crucial role in running the ceremony. That's why Parhata need to mastering in addressing someone.

\section{Research Methods}

Research method apply in this research was descriptive qualitative analysis which use as a method of research because the result of this study intends to describe the use of logicosemantic relations in Bataknese Traditional Wedding Ceremony. Flick (2009:46), qualitative research is mainly concerned with the production and analysis of texts, such as transcripts and other analytic materials. In this research, the descriptive qualitative design was used to analyze the types of logico-semantic relations and how they were used in Bataknese Traditional Wedding Ceremony. In this study, the sources of data were taken from the utterances of parhata in the recorded video of wedding ceremony which have 3 hours duration. The data of the study were taken from all clause complexes found in Parhata's utterances.

The techniques of collecting data were the following (1) video Bataknese wedding ceremony, (2) Transcribing the utterances of parhata, (3) Separating the text into clauses. The procedures of analyzing data as the following, (1) Identifying clause complexes of Parhata's utterances, (2) Determining the kinds of logical relations. (3) Tabulating the kinds of logical relations in to table, (4) Describing the finding to know how Parhata uses the kinds of logical relations, (5) Explaining the finding to know how Parhata uses the kinds of logical relations. 


\section{Results and Discussion}

\subsection{Findings}

After watching the video, transcribing, identifying, and separating the data. There were 80 clause complexes found in Bataknese Traditional wedding ceremony. The table below shows the logico-semantic relation in Bataknese traditional wedding ceremony.

Table 1. The percentage types of logico-semantic relations

\begin{tabular}{|c|c|c|c|}
\hline \multicolumn{2}{|c|}{ Logico-semantic relation } & \multirow{2}{*}{$\begin{array}{c}\text { Total number } \\
\quad 27\end{array}$} & \multirow{2}{*}{$\begin{array}{c}\text { Percentage } \\
33.75 \%\end{array}$} \\
\hline 1. & Paratactic enhancement & & \\
\hline 2. & Hypotactic enhancement & 23 & $28.75 \%$ \\
\hline 3. & Paratactic extension & 12 & $15 \%$ \\
\hline 4. & Paratactic elaboration & 10 & $12.5 \%$ \\
\hline 5. & Hypotacticelaboration & 5 & $6.25 \%$ \\
\hline 6. & Hypotacticextension & 2 & $2.5 \%$ \\
\hline 7. & Paratacticlocution & 1 & $1.25 \%$ \\
\hline 8. & Hypotacticlocution & 0 & $0 \%$ \\
\hline 9. & Paratacticidea & 0 & $0 \%$ \\
\hline 10. & Hypotacticidea & 0 & $0 \%$ \\
\hline To & & 80 & $100 \%$ \\
\hline
\end{tabular}

Based on the data collected, it was found that the paratactic enhancement was dominantly used in Bataknese Wedding Ceremony. It can be seen from the table of distribution of logical relation, which shows that the frequency of paratactic enhancement were 27 clause complexes $(33.75 \%)$. Meanwhile the lowest frequency used is hypotactic locution, paratactic idea, and hypotactic idea.

\subsection{Discussion}

There were seven of ten types of logical relation are found, that are paratactic elaboration, hypotactic elaboration, paratactic extension, hypotactic extension, paratactic enhancement, hypotactic enhancement, and paratactic locution. Meanwhile, hypotactic $\backslash \mathrm{c}$ locution, paratactic idea and hypotactic idea were not found. The speaker should use the appropriate word to deliver the massages and idea. The idea mostly used the equality of relationship that is paratactic. It indicate the correlation of the idea in the same status which used the independent clause in the utterances which are combined by conjunction, verb and adverbial clause.

From seven of logical relations types of logical relations types which are used by Parhata. It is paratactic enhancement mostly occurs which indicates that Parhata lead the event by the circumstantial feature that the most frequently occurring subtypes are those of time and cause to the listeners. It can be seen from the use of conjunction to indicate the relationship in order to convey the information. Hypotactic locution, paratactic idea and hypotactic idea were three missing type of logico semantic relation in Bataknese Traditional wedding ceremony. It indicates that Parhata is the person who control the event and need no idea to deliver someone else opinion. 


\section{Conclusion}

After analyzing logico-semantic relation in Bataknese Traditional Ceremony which uttered by Parhata, the following conclusions are drawn:

1. Only seven of ten types of logical relation that found in Bataknese traditional wedding ceremony, they are paratactic elaboration, hypotactic elaboration, paratactic extension, hypotactic extension, paratactic enhancement, hypotactic enhancement, and paratactic locution. Meanwhile three of them were missing, they are hypotactic locution, paratactic idea and hypotactic idea.

2. The mostly used to related one clause to another is conjunction, adverbial clause, verb and preposition.

3. It has the feature [+institutionalized/social/+specialized] based on context of situation language that used by Parhata.

\section{References}

Ajie \& Opuku. 2017. The Expansion Relations of Clause Complexing (CC) in the Editorials of the Daily Graphic. Winneba- Central Region, Ghana: University of Education.

Anggara. 2015. Tactic System and Logico-Semantic Relations of Clause Complexes in Asean Free Trade Area (AFTA) Agreement. Semarang: Dian Nuswantoro University.

Bloor, Thomas \& Mariel. 2004. The Functional Analysis of English (2nded) London: Hodder Arnold.

Eastwood, J. 1994. Oxford Guide to English Grammar. Oxford University Press.

Febrina, D. 2017. Logico-Semantic Relations in Mendez Utterances In Argo. Faculty language and art. Medan: State University of Medan.

Halim, A. 1984. Morfologi dan Sinteksis Bahasa Batak Simalungun. Jakarta Timur.

Halliday, M., \& Matthiessen, C. 2004. An introduction to Functional Grammar (3rded.). London: Hodder Arnold.

Halliday, M., \& Matthiessen, C. 2014. Introduction to Functional Grammar (4rded.).USA: Routledge.

Hancock, B \& Ockleford, E. 2007. An Introduction to Qualitative Research. University of Birmingham.

Martin, J.R. \& Matthiessen, C.1997. Working With Functional Grammar (1sted.) Great Britain: ArnoldLondon.

Purba, Jaefendi. 2002. Adat Perkawinan Dalam Budaya Simalungun. Daerah Istimewa Yogyakarta.

Saragih, Amrin. 2014. Discourse Analysis: A Study on Discourse Based on Systemic Functional Linguistic Theory. Medan: Universitas Negeri Medan.

Saragih, Amrin. 2017. Variation and Functional Varieties of Language. Mahara Publishing: Tangerang, Banten.

Siahaan \& Napitupulu. 2014. The logical meanings of the traditional wedding speechesof the Batak Toba people. Medan-Pematangsiantar: HKBP Nommensen University.

Sinaga, S. 2014. Buku Adatni Simalungun. Cetakan ke III. Pematang Raya.

Sulistyaningrum \& Rasyid. 2015. The Logico-Semantic Relation of Students

Presentation in Acceleration Program of SMA Lab School Jakarta. Jakarta: State University of Jakarta. 